\title{
BAGIAN KETIGA MISTISISME KRISTEN DALAM PERSPEKTIF YOHANES 17:20-23
}

Yohanes sebagai produk kedua dari dunia Helenistis di mana berita Yesus tentang Kerajaan Allah itu telah disesuaikan ke dalam agama keselamatan Helenistis. Selama bertahun-tahun pendapat kritikal yang berlaku adalah bahwa Injil Yohanes adalah 'Injil kaum Helenistis'; ditulis oleh seorang ahli pikir Yunani untuk orang-orang Yunani; menandai bagian yang paling menentukan dalam helenisasi iman Kristen. Dari sudut pandang ini, Injil itu jauh terpisah dari Yesus. Injil itu menceritakan kebenaran kekal, bukan fakta objektif; dalam teologi, bukan sejarah. Mukjizat-mukjizatnya hanya lambang dari kenyataan rohani; ungkapan-ungkapannya bernada alegoris. Sejak itu, penemuan tiga papyrus berisikan seluruh atau sebagian dari Yohanes yang ditulis pada permulaan abad kedua, meniadakan pandangan-pandangan yang demikian. Namun, penyelidikan berlangsung terus untuk menemukan kedudukan dalam hidup agama yang mungkin dapat menerangkan bahasa dan teologi Injil Keempat. ${ }^{1}$

\footnotetext{
${ }^{1}$ George Eldon Ladd, Teologi Perjanjian Baru, Jilid 1, Urbanus Selan, terj., (Bandung: Kalam Hidup, 2002), 288
} 
Tidak dapat disangkal bahwa beberapa terminologi karakteristik Yohanes sangat serupa dengan idiom Hermetika, yaitu kumpulan tulisan agama yang dibuat di Mesir kira-kira dalam abad kedua atau ketiga. Tulisan-tulisan ini banyak mengungkapkan tentang terang dan hidup, perkataan dan keselamatan oleh pengetahuan demikian juga regenerasi atau kelahiran baru. C.H. Dodd merasa bahwa Hermetika adalah latar belakang yang berharga untuk memahami Injil Yohanes. Namun demikian, banyak terminologi teologis yang khusus dalam Hermetika seperti misalnya gnosis (pengetahuan), mysterion (misteri, rahasia), athanasia (amoral), demiurgos (pembangun, pencipta), nous (hati, pikiran, maksud, pengertian) kurang didapati dalam Yohanes dan idiom Yohanes secara umum lebih menyerupai LXX (Septuaginta) daripada Hermetika. $^{2}$

Menurut C.K. Barrett, ketika Yohanes menulis Injil, "tradisi Yunani" dalam arti filsafat rasionalnya, sudah jatuh (collapsed) dari zaman keemasannya. Tempat itu sudah direbut oleh tradisi Helenistik. Keadaan ini membuat mazhab rasionalisme melakukan kompromi dengan mistisisme, baik dalam filsafat maupun agama. Karena itu dalam prakteknya sakramen, asketisme, dan juga pesta pora diberi "cita rasa" sebagai pencarian terhadap yang llahi serta penyatuan dengan yang Ilahi. Dari literatur Mandean mulai abad VII dan VIII dapat direkonstruksikan gerakan kembali menuju masa pra-kekristenan yang

${ }^{2}$ Ibid., 289 
menunjukkan sinkretisme antara filsafat Helenistik populer dan mistik Timur yang menghasilkan agama "proto-gnostic" (pengetahuan dasar). ${ }^{3}$

Dari semua penulis kitab Injil tidak ada yang mencatat namanya sendiri. Dan jika kita mencermati Injil Yohanes, maka sebenarnya nama Yohanes ataupun Yakobus, saudaranya, tidak pernah muncul dalam Injil Yohanes. Hal ini mengherankan karena dia sebenarnya seorang yang penting di antara para murid Tuhan Yesus. Namun demikian, isi kitab Yohanes sendiri menolong kita untuk menentukan siapakah penulisnya. Tenney menyatakan bahwa dari Injil itu sendiri dapat terlihat beberapa fakta tentang diri penulis. Yang pertama, ia adalah seorang Yahudi yang sudah terbiasa berpikir dalam bahasa Aram, meskipun Injil ini ditulis dalam bahasa Yunani. Sang penulis sangat mengenal adat-istiadat Yahudi. Yang kedua, ia adalah seorang Yahudi Palestina, yang mempunyai hubungan pribadi dengan negeri itu terutama dengan Yerusalem dan sekitarnya (Yoh. 9:7; 11:18; 18:1). ${ }^{4}$ Menurut pasal yang terakhir, ia adalah "murid yang dikasihi Yesus" (Yoh. 21:20-24). Brill menyatakan bahwa "murid yang dikasihi" sendirilah yang menulis kitab ini. ${ }^{5}$ Artinya murid yang dikasihi oleh Tuhan Yesus, dialah yang menulis Injil Yohanes. Serta dalam konteks ini dapat terlihat hubungan yang erat antara Petrus dan "murid yang dikasihi" tersebut (bdk. Yoh. 21:20-24).

${ }^{3}$ C.K. Barrett, The Gospel According To St. John: An Introduction with Commentary and Notes on the Greek Texk, (Philadelphia, The Wesminster Press, 1978), 28

${ }_{5}^{4}$ Merrill C. Tenney, Survei Perjanjian Baru, terj., (Malang: Gandum Mas, 2006), 232-233

${ }^{5}$ J. Wesley Brill, Tafsiran Injil Yohanes, terj., (Bandung: Kalam Hidup, 1976), 11 
Pertama-tama bisa dipastikan bahwa dia merupakan salah satu dari keduabelas murid Yesus, karena dia hadir pada waktu perjamuan terakhir serta bertanya kepada Yesus siapa yang akan menyerahkan Tuhan Yesus, dan Petrus lah yang menyuruh hal itu (Yoh. 13:23, 25). Dari hal itu, kemungkinan bahwa murid ini dekat kepada Petrus dan Tuhan Yesus. Murid yang dikasihi ini juga yang diminta untuk menerima ibu Yesus sebagai ibunya sendiri (Yoh. 19:26-27), dan dialah yang berlari dengan Petrus ke kuburan Yesus (Yoh. 20:25). Haruslah diperhatikan juga bahwa dalam konteks ini "murid yang dikasihi" disebut bersama Petrus (Yoh. 13:24), Yudas Iskariot (Yoh. 13:2, 26-28), Tomas (Yoh. 14:5), Filipus (Yoh. 14:8), dan Yudas yang bukan Iskariot. Karena mereka disebut dengan nama, maka kemungkinan besar bukanlah mereka yang disebut "murid yang dikasihi Yesus". Terakhir yang perlu kita perhatikan adalah bahwa "murid yang dikasihi" termasuk dalam kelompok orang yang pergi menangkap ikan bersama dengan Petrus (Yoh. 21:2-3). Yang ikut ialah anak-anak Zebedeus (yaitu Yakobus dan Yohanes), Tomas dan Filipus, serta dua murid yang lain.

Berkaitan dengan identitas "murid yang dikasihi" tersebut Tulluan menyatakan bahwa:

Jelaslah bahwa dia seorang Rasul. Tetapi tidak mungkin namanya Yakobus, karena Yakobus itu dibunuh pada tahun 44, yaitu sebelum Injil ini ditulis (Kis. 12:2). Juga Petrus, Tomas, dan Filipus tidak cocok, karena nama mereka semua disebut dalam bentuk "orang ke3" ("dia", "mereka") dan tidak dalam bentuk "orang pertama" ("saya"). Si penulis tidak menyebutkan namanya. Walapun demikian dia terkenal, dan jelaslah bahwa dia mempunyai wibawa rohani. Hanya 
ada satu kemungkinan saja, yaitu Yohanes anak Zebedeus. Tidak ada rasul-rasul lain yang cocok. ${ }^{6}$

Dari hal-hal tersebut di atas dapatlah ditarik kesimpulan bahwa "murid yang dikasihi Yesus" ialah Yohanes. Hal ini menggarisbawahi posisi Yohanes sebagai murid yang paling dekat dengan Tuhan Yesus. Demikian juga dia sering bersama dengan rasul Petrus. Searah dengan hal ini Santoso menegaskan bahwa karena dekatnya dengan Tuhan Yesus inilah maka rasul Yohanes disebut sebagai "murid yang dikasihi-Nya", bahkan ia diizinkan bersandar dekat kepada-Nya, di sebelah kanan-Nya. Baginya kalimat dalam Yohanes 1:14 dan 1 Yohanes 1:1 sudah jelas menunjukkan pengalaman yang kaya dan nyata dari rasul Yohanes terhadap Tuhannya dimana dia sebagai murid yang dikasihi-Nya. ${ }^{7} \mathrm{Hal}$ di atas didukung oleh kesaksian dari gereja mulamula. Barrett mengutip dari tulisan Eusebius menuliskan bahwa:

The former [Irenaeus] in the second book of his work Against Heresies, writes as follows: 'And all the elders that associated with John the disciple of The Lord in Asia bear witness that John delivered it [the gospel] to them. For he remained among them until the time of Trajan.' And in the third book of the same work he attests the same thing in the following words: 'But the church in Ephesus also, which was founded by Paul, and where John remained until the time of Trajan, is a faithful witness of the apostolic tradition. ${ }^{8}$

Sebagai sumber Irenaeus cukup dekat dengan Yohanes, karena dia merupakan murid dari Polykarpus (bishop di Smirna), yang merupakan murid dari rasul Yohanes sendiri. Atas dasar hubungan dekat dengan Yohanes ini

\footnotetext{
${ }^{6}$ Ola Tulluan, Introduksi Perjanjian Baru, (Batu: Departemen Literatur YPPII, 1999), 74

${ }^{7}$ David Iman Santoso, Teologi Yohanes: Intisari Dan Aplikasinya, (Malang: Literatur SAAT, 2007), 14-15

C.K. Barrett, The Gospel According To St. John..., 100
} 
Irenaeus menulis: "Setelah itu, Yohanes, murid Tuhan Yesus itu, yang berpaling kepada Tuhan waktu perjamuan malam, mempublikasikan Injilnya, waktu dia berada di Efesus". ${ }^{9}$ Hal senada juga diungkapkan Guthrie dalam tulisannya yang menyatakan bahwa:

Sampai dengan Irenaeus, tidak ada penulis yang menyebutkan nama penulis Injil Yohanes. Irenaeus tidak hanya menyebut bahwa penulis adalah Yohanes murid Yesus, tetapi juga bahwa Yohanes menerbitkan Injil di Efesus dan tinggal di kota itu sampai masa Trajan. Eusebius mencatat bahwa guru Irenaeus adalah Polikarpus, yang mengklaim belajar di bawah Yohanes. Eusebius juga melaporkan perjumpaan Yohanes dengan Cerinthus di Efesus. Rujukan lain kepada Polikarpus ditemukan dalam surat Irenaeus kepada Florinus, di mana ia mengingatkan teman masa kecilnya tentang perjumpaan awal mereka dengan Polikarpus dan tentang cerita Polikarpus akan perbincangannya dengan Yohanes dan orang-orang lain yang telah melihat Tuhan. Karena itu jelas bahwa berdasarkan kesaksian Polikarpus, Irenaeus menerima rasul Yohanes sebagai penulis Injil Keempat dan percaya bahwa Injil ini diterbitkan di Efesus. ${ }^{10}$

Kesaksian serupa dapat kita temukan dalam Polikratus, yang menjabat sebagai uskup Efesus (189-198 M). la menulis surat kepada Viktor dari Roma bahwa Yohanes, yang menjadi saksi dan guru, sekarang terbaring di Efesus. ${ }^{11}$ Selain itu juga ada fragmen-fragmen tua yang berisikan Yohanes 18:31-33 dan 37-38. Fragmen-fragmen itu berasal dari sekitar tahun 125 AD. Jelaslah bahwa Injil ini cepat tersebar kemana-mana. Hal ini tidak mungkin bilamana Injil ini

${ }^{9}$ F.F. Bruce, The Gospel of John, (Grand Rapids, Michigan: W.B. Eerdmans Publishing Company, 1984), 11

10 Donald Guthrie, Pengantar Perjanjian Baru, Volume 1, Hendry Ongkowidjojo, terj., (Surabaya: Momentum, 2008), 234-235

${ }^{11}$ William Hendriksen, New Testament Commentary: The Gospel of John, (Pennsylvania: The Banner Of Truth Trust, 1959), 24 
merupakan Injil yang palsu. Tetapi sejak permulaan Injil ini diterima sebagai Injil Yohanes. $^{12}$

Yohanes menulis, "Firman itu telah menjadi manusia, dan diam di antara kita, dan kita telah melihat kemuliaan-Nya" (Yoh. 1:14). Boleh dikatakan bahwa Yohanes telah menyaksikan semua hal yang tertulis dalam kitab itu. Guthrie menjelaskan bahwa menurut beberapa teolog, "kita" di surat Yohanes menunjuk kepada orang Kristen secara umum, tetapi pernyataan dalam Injil Yohanes akan sangat kehilangan arti jika tidak dipahami sebagai klaim saksi mata. Kata "melihat" di sini lebih bersifat fisik dan bukannya secara rohani. ${ }^{13}$ Jadi, jelaslah bahwa kitab Injil Keempat menampilkan seorang tokoh yang bisa kita sebut sebagai saksi. Berkaitan dengan hal tersebut, Tenney menyatakan bahwa :

...ia adalah seorang saksi mata dari kejadian-kejadian yang direkamnya. Baik di dalam 1:14, "kita telah melihat kemulian-Nya...," dan dalam 19:35, di mana ia berbicara melalui orang ketiga, "orang yang melihat hal itu sendiri yang memberi kesaksian ini," ia menyatakan telah menyampaikan bagian dari pengalaman pribadinya. Beberapa sentuhan kecil di sepanjang Injil ini makin menguatkan kesan ini. Jam di saat mana Yesus duduk di tepi sumur (4:6), jumlah dan ukuran tempayan pada pesta perkawinan di Kana (2:6), berat dan harga minyak yang digunakan oleh Maria untuk meminyaki kaki Yesus $(12: 3,5)$, dan perincian pengadilan Yesus (pasal 18-19) adalah hal-hal yang tidak banyak mempengaruhi jalannya cerita namun menunjukkan kehadiran penulis. ${ }^{14}$

Dengan demikian, tentang dirinya sendiri penulis menggarisbawahi bahwa dia adalah saksi mata dari peristiwa-peristiwa yang dilaporkannya. Jelaslah bahwa dia tidak hanya seorang penonton. Dia tidak hanya melihat apa yang

\footnotetext{
${ }^{12}$ Ola Tulluan, Introduksi Perjanjian Baru..., 75

${ }_{13}^{13}$ Donald Guthrie, Pengantar Perjanjian Baru..., 220

${ }^{14}$ Merrill C. Tenney, Survei Perjanjian Baru..., 233
} 
terjadi. Dia begitu yakin bahwa kesaksiannya benar dan menguraikan banyak peristiwa secara rinci.

Menurut tradisi Kristen, Yohanes menghabiskan tahun-tahun yang kemudian dari hidupnya di Efesus, di mana dia menyelenggarakan pelayanan memberitakan Injil dan mengajar, dan juga menulis. Dari sini dia dibuang ke pulau Patmos ketika kaisar Domitian memerintah. ${ }^{15}$ Injil yang ia tulis tampaknya menunjukkan pengenalan akan tradisi Sinoptis dan kemungkinan ditulis sekitar tahun 80 dan $90 \mathrm{M}^{16}$ Brill menegaskan bahwa tidak diketahui secara pasti kapan Yohanes menulis Injil itu, tetapi diduga antara tahun 80 dan 90. Menurut keterangan yang diperoleh dari Dead Sea Scrolls, mungkin Injil itu ditulis antara tahun 65 dan 75. Dengan demikian, pada waktu itu Yohanes berumur antara delapan puluh dan sembilan puluh tahun. Lebih lanjut ia menjelaskan bahwa berdasarkan sejarah Gereja, Yohanes telah pergi ke Asia Kecil dan menjadi pemimpin dalam pekerjaan Tuhan di sana. Pada masa tuanya ia tinggal di Efesus dan di sana ia menulis Injilnya. ${ }^{17}$

Terdapat bukti-bukti awal bagi peredaran Injil Yohanes selama paruh pertama abad kedua. Bukti terawal adalah Papirus Rylands 457 yang menurut Sir F. Kenyon berasal dari abad kedua. Terlepas dari apakah papirus ini dipakai oleh Kristen ortodoks atau gnostik, hal ini membuktikan Injil Yohanes telah ada

${ }^{15}$ Ola Tulluan, Pengantar Tulisan-Tulisan Yohanes Dan Inti Berita Kitab Wahyu, (Malang: Dep. Pendidikan Theologia YPPII,), 5-6

${ }^{16}$ Charles F. Pfeiffer and Everett F. Harrison (eds), The Wycliffe Bible Commentary: Tafsiran Alkitab Wycliffe, Volume 3: Perjanjian Baru, (Malang: Gandum Mas, 2001), 299

${ }_{17} \mathrm{~J}$. Wesley Brill, Tafsiran Injil Yohanes..., 16 
pada masa itu. Penemuan fragmen ini, bersama dengan Papirus Egerton 2, secara selektif membungkam pendapat radikal yang menganggap Injil Yohanes baru ditulis di akhir abad kedua. Jika rasul Yohanes adalah penulisnya, maka Injil Yohanes tidak bisa ditulis lebih lama dari $100 \mathrm{M}$, dan bahkan kecil sekali kemungkinan Injil ini baru terbit pada masa itu. ${ }^{18} \mathrm{Hal}$-hal di atas diperkuat oleh Tulluan yang memberikan beberapa alasan mengapa banyak penafsir menduga bahwa Injil Yohanes ditulis menjelang akhir abad pertama, yaitu:

1. Ada kemungkinan besar bahwa Yohanes sudah mengenal Injilinjil Sinoptis pada waktu dia menulis Injilnya. Itu berarti bahwa Injil Yohanes ditulis sesudah tahun 70 AD.

2. Sejarah gereja membuktikan bahwa Injil Yohanes sudah dikenal dalam kalangan yang luas dari permulaan abad II. Sebabnya adalah bahwa dalam katakombe-katakombe abad II ditemukan lukisan-lukisan tentang isi Injil Yohanes. Contohnya: Yesus menghidupkan anak Yairus. Inilah lukisan-lukisan katakombe yang paling tua; diperkirakan dari awal abad II.

3. Para bapa gereja (seperti Irenaeus, Ignatius, Yustin Martir) mengatakan bahwa Injil Yohanes diselesaikan tidak lama sebelum Yohanes meninggal, yaitu menjelang akhir abad I. ${ }^{19}$

Dengan demikian, dapat dipastikan bahwa Injil Yohanes ditulis antara tahun 80 dan $90 \mathrm{AD}$.

Dalam Yohanes 20:30-31 terdapat pernyataan yang sangat jelas tentang tujuan penulis dalam menulis kitab tersebut. ${ }^{20}$ Santoso menjelaskan bahwa frasa "telah dicatat" dalam Yohanes 20:30 adalah dalam bentuk perfect tense yang mengandung arti bahwa Injil Yohanes itu telah ditulis dan seterusnya tetap dalam keadaan tertulis yang mempunyai nilai permanen yang berlaku sejak

\footnotetext{
${ }^{18}$ Donald Guthrie, Pengantar Perjanjian Baru..., 260-262

${ }^{19}$ Ola Tulluan, Pengantar Tulisan-Tulisan Yohanes..., 5

${ }^{20}$ Merrill C. Tenney, Injil Iman, Rumkeny, terj., (Malang: Gandum Mas, 2003), 25
} 
waktu itu dan seterusnya. Tujuan penulisan itu adalah penginjilan, yaitu supaya kita percaya. ${ }^{21}$ Menurut Tulluan, ada dua hal yang ditekanan dalam Yohanes 20:30-31, yaitu: Pertama, Yohanes tidak bermaksud untuk menulis riwayat hidup Tuhan Yesus. Mengenai tanda-tanda yang dibuat oleh Yesus ada "banyak yang tidak tercatat dalam kitab ini". Kedua, bahan yang ada dalam kitab Yohanes, dicantumkan "supaya kamu percaya bahwa, Yesuslah Mesias, Anak Allah, dan supaya kamu oleh imanmu memperoleh hidup dalam nama-Nya”. ${ }^{22}$ Berdasarkan hal-hal di atas kita dapat menduga bahwa inti Injil adalah kisah Yohanes sendiri mengenai peristiwa-peristiwa penting yang dipilih dalam kehidupan Kristus.

Sementara itu, Tenney menambahkan bahwa ada kemungkinan Injil Yohanes sengaja ditulis untuk melengkapi berita tentang kehidupan dan pekerjaan Yesus yang sudah ada pada masa itu dan yang sudah dinyatakan secara tertulis dalam Injil-Injil Sinoptis. ${ }^{23}$ Hal tersebut didukung R.V.G. Tasker yang mengutip pernyataan Clement dari Alexandria, yaitu: 'Last of all', wrote Clement of Alexandria, 'John, perceiving that the eternal facts ( $\tau \alpha \sigma \bar{o} \mu \alpha \tau \iota \kappa \alpha)$ had been made plain in the Gospels, being urged by his friends and inspired by the Spirit, composed a spiritual ( $\pi \nu \epsilon \nu \mu \alpha \iota \kappa o \nu)$ Gospel. ${ }^{24}$ Dengan kata lain, Clement dari Alexandria percaya Injil Yohanes adalah pelengkap yang berbeda jenis

\footnotetext{
${ }^{21}$ David Iman Santoso, Teologi Yohanes: Intisari Dan Aplikasinya..., 17

${ }^{22}$ Ola Tulluan, Pengantar Tulisan-Tulisan Yohanes..., 8

${ }^{23}$ Merrill C. Tenney, Survei Perjanjian Baru..., 244

${ }^{24}$ R.V.G. Tasker, Tyndale New Testament Commentaries: John, (Grand Rapids, Michigan:
} Wm. B. Eerdmans Publishing Company, 1994), 24-25 
dengan Sinoptik. Selain itu, Guthrie menegaskan bahwa meski bukti yang ada tidak cukup kuat untuk menunjukkan kebergantungan Yohanes pada Sinoptik, ada cukup petunjuk bahwa penulis mengasumsikan pembacanya telah mengenal isi dari Injil-Injil lain. Hanya di bawah hipotesis seperti itu, pemilihan materinya dapat dipahami secara masuk akal. ${ }^{25}$

Jika Injil Yohanes dibandingkan dengan Sinoptik nampak bahwa, di samping adanya perbedaan-perbedaan yang jelas, juga terdapat banyak keserupaan yang nyata. ${ }^{26}$ Berkaitan dengan keserupaan Injil Yohanes dan InjilInjil Sinoptik, Guthrie menerangkan bahwa baik Sinoptik maupun Injil Yohanes mencatat tentang Yohanes Pembabtis, pemanggilan para murid, pengakuan Petrus, masuknya Yesus ke Yerusalem, perjamuan terakhir, dan berbagai kisah penderitaan Yesus. Selain itu, semuanya mengisahkan penyucian Bait Suci dan pengurapan Yesus, meski dalam latar yang berbeda. ${ }^{27}$ Tetapi meskipun Injil Yohanes memuat tentang wawasan peristiwa yang sama dengan yang termuat dalam kitab-kitab Injil lainnya, ia sangat berbeda dalam struktur maupun gayanya.

Sementara Injil-Injil Sinoptis hanya menyebutkan satu Paskah, dan karena itu tampak seperti membatasi pelayanan Kristus hanya selama satu tahun, Yohanes menyebutkan paling sedikit tiga Paskah (Yoh. 2:23; 6:4; 13:1), yang

${ }^{25}$ Donald Guthrie, Pengantar Perjanjian Baru..., 248

${ }^{26}$ Raymond E. Brown, Tafsir Perjanjian Baru: Injil dan Surat-Surat Yohanes, (Yogyakarta: Penerbitan Yayasan Kanisius, 1981), 15

${ }^{27}$ Donald Guthrie, Pengantar Perjanjian Baru..., 266-267 
berarti bahwa pelayanan-Nya berlangsung selama tiga tahun. ${ }^{28}$ Dalam Injil Yohanes, tempat di mana Yesus melakukan pelayanan-Nya berbeda dari tempat yang diceritakan oleh tiga kitab Injil yang lain. Menurut tiga kitab Injil yang lain pusat pelayanan Yesus adalah Galilea, dan Yesus baru pergi ke Yerusalem dalam minggu terakhir dari hidupnya. Sedangkan di dalam Injil Yohanes pusat pelayanan Yesus adalah Yerusalem dan Yudea. Hanya kadangkadang saja Yesus pergi ke Galilea (Yoh. 2:1-13; 4:35-5:1; 6:1-7:14). ${ }^{29}$ Beberapa rincian sejarah menimbulkan persoalan. Salah satu contohnya ialah pembersihan Bait Allah, Injil Yohanes menempatkan upacara pembersihan Bait Allah pada permulaan masa pelayanan Yesus (Yoh. 2:13, 22), sedang tiga kitab Injil yang lain menempatkannya pada akhir masa tersebut (Mrk. 11:15-17; Mat. 21:12, 13; Luk. 19:45, 46). ${ }^{30}$ Yang lainnya adalah bahwa kitab Injil Yohanes menganggap penyaliban Yesus terjadi satu hari sebelum Paskah, sedang ketiga Injil yang lain menganggap jatuh tepat pada hari Paskah. Tekanan-tekanan paling khas dalam Injil Yohanes kurang ditemukan dalam Injil Sinoptis. Barangkali idiom Yohanes yang paling khas adalah ungkapan tentang Eүo $\epsilon \iota \iota \iota$ (aku ini). ${ }^{31}$

Menanggapi perbedaan-perbedaan seperti di atas Santoso menerangkan bahwa penulis Injil Yohanes merasa bahwa Injil Sinoptik sudah cukup banyak

\footnotetext{
${ }^{28}$ Charles F. Pfeiffer and Everett F. Harrison (eds), The Wycliffe Bible Commentary..., 298

${ }^{29}$ William Barclay, Pemahaman Alkitab Setiap Hari: Injil Yohanes, Fs. 1-7, S. Wismoady Wahono, terj., (Jakarta: BPK Gunung Mulia, 1983), 3

${ }_{31}^{30}$ Charles F. Pfeiffer and Everett F. Harrison (eds), The Wycliffe Bible Commentary..., 298

${ }^{31}$ George Eldon Ladd, Teologi Perjanjian Baru, Jilid 1, Urbanus Selan, terj., (Bandung: Kalam Hidup, 2002), 286-287
} 
menyajikan kisah, ajaran dan pekerjaan Tuhan Yesus di Galilea, maka sekarang ia menekankan kisah ajaran dan pekerjaan Tuhan Yesus di Yudea. Dengan demikian sekarang bisa dikatakan telah lengkaplah hikayat Yesus sebagaimana dicatat dalam keempat Injil ini. Selain itu, umumnya diakui bahwa Injil Yohanes ditulis agak belakangan dibandingkan dengan Injil Sinoptik. Hal ini berarti bahwa penulisan Yohanes telah mengalami masa renungan atau meditasi yang cukup lama tentang Inkarnasi, Injil Yesus Kristus, serta segala mujizat dan ajaran Kristus. Di situlah gaya penulisan Injil Yohanes nampak begitu penuh dengan makna dan bernada teologis. ${ }^{32}$ Searah dengan hal tersebut Tulluan menjelaskan bahwa ketiga Injil pertama memamerkan Tuhan Yesus, Yohanes menafsirkannya. Ketiga Injil pertama sifatnya bercerita, sedangkan Injil Yohanes sifatnya mengajar. Itu berarti bahwa Injil Yohanes tidak mengemukakan sesuatu yang baru. Dia hanya memberikan uraian yang lebih konkrit dan lebih panjang atas kebenaran yang sudah ada dalam tiga Injil pertama. ${ }^{33}$

\section{UNIO MYSTICA DALAM PERSPEKTIF YOHANES 17:20-23}

Dalam bagian ini penulis akan memaparkan tentang penelaahan teks dengan menggunakan teks Yunani dan beberapa perbandingan terjemahan untuk memahami arti literal dengan tepat. Selain itu, juga membandingkan hasil penelaahan tersebut dengan beberapa penafsir sehingga dapat mengambil kesimpulan yang tepat.

\footnotetext{
32 David Iman Santoso, Teologi Yohanes: Intisari Dan Aplikasinya..., 22-23

${ }^{33}$ Ola Tulluan, Introduksi Perjanjian Baru..., 85-86
} 


\section{Kesatuan dengan Allah Mendasari Kesatuan Orang Percaya (Ayat 20-21)}

Ayat 20

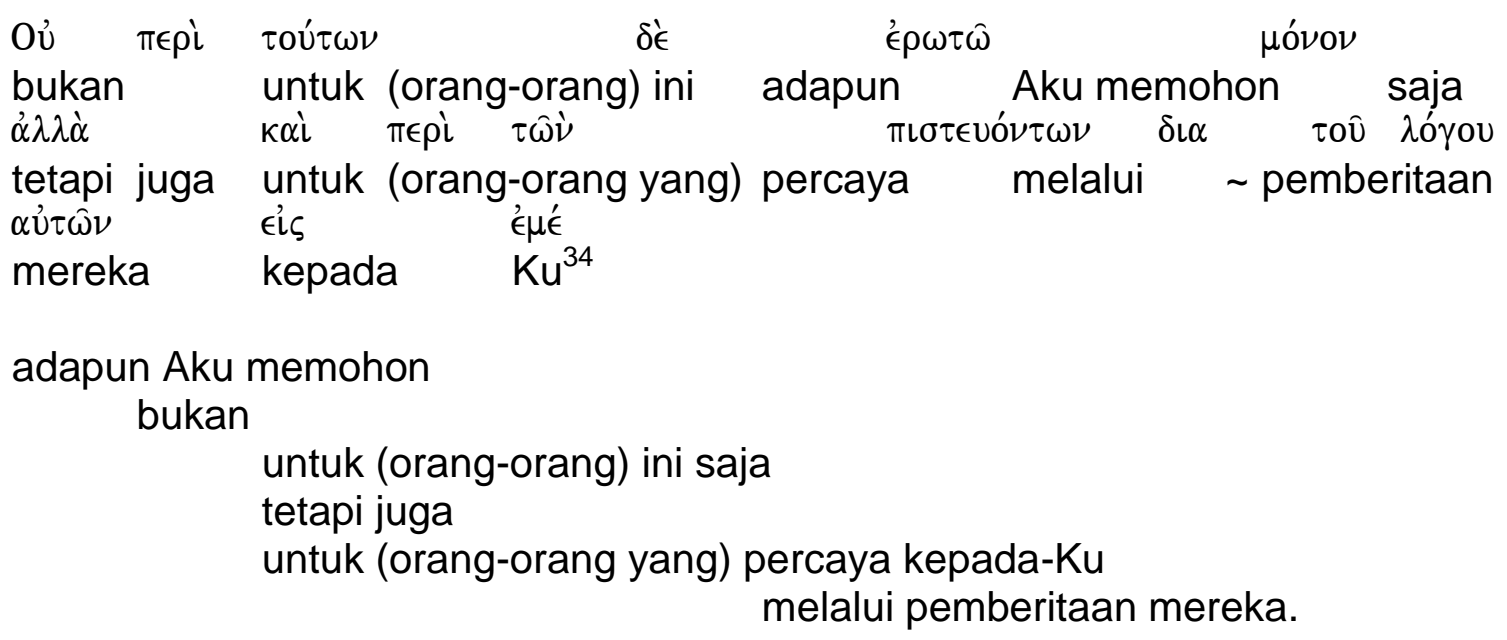

ITB:Dan bukan untuk mereka ini saja Aku berdoa, tetapi juga untuk orangorang, yang percaya kepada-Ku oleh pemberitaan mereka;

NIV: My prayer is not for them alone. I pray also for those who will believe in me through their message,

NKJV: I do not pray for these alone, but also for those who will believe in Me through their word;

NLT: I am praying not only for these disciples but also for all who will ever believe in me because of their testimony.

Dalam ayat 20 ini dinyatakan bahwa Yesus bukan hanya berdoa untuk "mereka ini saja", kata "mereka ini" dalam teks Yunani memakai kata $\tau o u ́ \tau \omega \nu$ (pronoun demonstrative genitive masculine plural from ổंos ${ }^{35}$ ). Kata tersebut

${ }^{34}$ Hasan Sutanto (ed), Perjanjian Baru Interlinear Yunani-Indonesia dan Konkordansi Perjanjian Baru (PBIK), Jilid I, (Jakarta: LAI, 2004), 593

${ }_{35}$ Samuel Bangster (ed), The Analytical Greek Lexicon, (Marylebone Lane, London: Samuel Bangster \& Sons LTD, 1971), 407 
merupakan kata ganti dan kata sifat petunjuk ini; inilah; dia. ${ }^{36}$ Kata ganti tunjuk tersebut biasa digunakan untuk meminta perhatian pada orang atau objek tertentu, dan seringkali dengan penekanan khusus "ini". Apabila kata penunjuk berdiri sendiri yaitu tiada kata benda yang diterangkannya maka artinya sama dengan kata sifat, yang berdiri sendiri. ${ }^{37}$ NIV menerjemahkannya menjadi "them", dan NKJV "these". Tetapi bila kita hanya melihat hal tersebut maka kita akan kesulitan untuk memahami siapkah yang dimaksud dengan "mereka ini", Alkitab versi New Living Translation memperjelas hal tersebut dengan memperluas terjemahannya menjadi "these disciples". Sehingga dapat disimpulkan bahwa yang dimaksudkan dengan "mereka ini" adalah para murid Tuhan Yesus, yaitu kesebelas murid. Hal itu dapat diperkuat dengan fakta bahwa Tuhan Yesus menaikkan doa ini setelah perjamuan malam terakhir bersama murid-murid-Nya. Selain itu, kita juga dapat memahami lebih lanjut bahwa $\tau o u ́ \tau \omega \nu$ adalah kata benda maskulin, orang ketiga jamak. Jadi hal itu menunjuk kepada orang laki-laki yang jumlahnya lebih dari satu. Berkaitan dengan hal tersebut di atas Ryle menjelaskan bahwa:

In this and the three following verses our Lord proceeds to name another thing that He prays for His people. He asks that they may be "one." He had already named this on behalf of the eleven Apostles. But He takes occasion now to enlarge the prayer, and to include others beside the eleven, -- the whole company of future believers. ${ }^{38}$

${ }^{36}$ Barclay M. Newman Jr., Kamus Yunani - Indonesia: Untuk Perjanjian Baru, John Miller \& Gerry van Klinken, terj., (Jakarta: BPK Gunung Mulia, 1994), 120

37 J.W. Wenham, Bahasa Yunani Koine, Lynne Newll, terj., (Malang: SAAT, 1987), 40

${ }^{38}$ J.C. Ryle, Expository Thoughts on the Gospels: John, Volume III, (London: James Clarke \& CO. LTD, 1957), 226 
Dengan demikian, jelaslah bahwa Tuhan Yesus tidak berdoa untuk muridmurid-Nya saja tetapi juga untuk "orang-orang yang percaya" kepada-Nya oleh pemberitaan murid-murid-Nya. Kata "percaya" dalam teks Yunani menggunakan kata $\pi\llcorner\sigma \tau \epsilon$ vó $\tau \omega \omega \nu$ (verb participle present active genitive masculine plural from $\pi\left\llcorner\sigma \tau \epsilon \dot{v} \omega^{39}\right)$. $\pi \iota \sigma \tau \epsilon \dot{v} \omega$ berarti beriman, percaya (terhadap/dalam) (Allah atau Kristus). ${ }^{40}$ Karena partisip adalah kata sifat verbal, maka partisip mempunyai ciri-ciri kata kerja dan kata sifat, sehingga sebagai kata kerja partisip mempunyai tense dan voice, dan dapat mempunyai objek. ${ }^{41}$ Dan dalam konteks

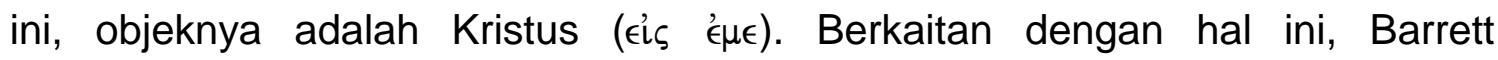
menyatakan bahwa the present participle $\pi \iota \sigma \tau \epsilon$ ó $\nu \tau \omega \nu$ is timeless ${ }^{42}$ sehingga tepatlah jika dalam NIV/NKJV diterjemahkan dengan "will believe". Hal ini didukung oleh Bernard yang menyatakan bahwa " $\iota \iota \tau \tau \epsilon \nu o ́ \nu \tau \omega \nu$ is a proleptic or anticipatory present participle, with the force of the future". ${ }^{43}$ Dari hal-hal tersebut dapatlah disimpulkan bahwa jangkauan doa Tuhan Yesus tersebut sangatlah luas, yaitu untuk orang percaya di segala abad. Tuhan Yesus bukan hanya berdoa untuk masa kini, tetapi juga untuk orang-orang percaya di masa depan.

Selanjutnya kata $\pi \iota \sigma \tau \epsilon v o$ tersebut diikuti dengan kata $\epsilon \iota \sigma$, yang artinya kepercayaan itu ditujukan kepada suatu oknum atau person. Selain itu, pada

${ }^{39}$ Samuel Bangster (ed), The Analytical Greek Lexicon..., 326

${ }^{40}$ Barclay M. Newman Jr., Kamus Yunani - Indonesia..., 133

41 J.W. Wenham, Bahasa Yunani Koine..., 130

${ }^{42}$ C.K. Barrett, The Gospel According To St. John..., 511

43 John Bernard, A Critical And Exegetical Commentary On The Gospel According To St. John, Vol. II, (Edinburg: T \& T. Clark, 1949), 576 
waktu kita percaya kepada seseorang, kita sepertinya masuk pada orang itu dan berserah sepenuhnya pada pribadi orang itu, dan kalau kita memperhatikan konteksnya maka akan jelas bahwa person yang menjadi objek iman tersebut adalah Tuhan Yesus.

Dalam Injil Yohanes iman menduduki tempat sangat mencolok, terlihat dari munculnya kata kerja $\pi \iota \sigma \tau \epsilon v o$ sampai 98 kali. ${ }^{44}$ Tetapi yang perlu digarisbawahi adalah bahwa kata benda "iman" tidak muncul dalam Injil Yohanes, walaupun kata kerjanya "percaya" sering muncul. Agaknya kegemaran Yohanes akan kata kerja itu disebabkan oleh kebutuhan untuk menekankan tindakan percaya daripada isi kepercayaan itu sendiri, karena di seluruh kitab Injil ini iman dianggap sebagai soal hubungan, bukan soal pengakuan. ${ }^{45}$ Iman bukanlah suatu persetujuan yang kosong terhadap hal-hal tentang firman, tetapi suatu persetujuan untuk menerima Kristus, dimana kita mempercayakan diri pada-Nya dan mematuhi Dia sebagai Juru Selamat. ${ }^{46}$ Santoso juga menegaskan bahwa percaya lebih ditekankan sebagai respons manusia terhadap tawaran kasih Allah dan anugerah keselamatan-Nya. ${ }^{47}$ Berkenaan dengan kata kerja "percaya" tersebut, Morris menjelaskan bahwa:

Ada empat cara Yohanes menggunakan kata kerja ini. Konstruksi yang paling sering ia gunakan ialah memakai kata kerja itu dengan kata depan "dalam/kepada" (eis); frasa tersebut kemudian biasanya

${ }^{44}$ J.D. Douglas (ed), Ensiklopedi Alkitab Masa Kini, Jilid I (A-L), terj., (Jakarta: YKBK/OMF, 2002), 432

${ }_{45}$ Donald Guthrie, Teologi Perjanjian Baru 2: Misi Kristus, Roh Kudus, Kehidupan Kristen, Jan S. Aritonang, terj., (Jakarta: BPK Gunung Mulia, 1996), 222-223

46 Thomas Manton, An Exposition of John 17, (Wilmington, Delaware: Sovereign Grace Publisher, 1972), 349

${ }^{47}$ David Iman Santoso, Teologi Yohanes: Intisari Dan Aplikasinya..., 78 
diterjemahkan dengan "percaya pada/kepada" dan mungkin arti yang mau disampaikan mirip dengan pengertian ada "dalam Kristus," meminjam istilah dari Paulus... Sesuai dengan pengertian Yohanes, kita harus memandang iman sebagai suatu penyerahan diri sepenuh hati yang oleh karenanya orang beriman menjadi satu dengan Kristus dan berada dalam Kristus. Yohanes banyak berbicara tentang "tinggal di dalam" Kristus (15:4 dst.); ke dalam keadaan semacam itulah iman membawa kita masuk. ${ }^{48}$

Jadi, jelaslah bahwa iman (percaya) kepada Tuhan Yesus akan membawa orang untuk memiliki persekutuan atau menjadi satu dengan-Nya. Kalau kita bandingkan dengan teks di bagian lain dalam Injil Yohanes maka kita akan mengerti bahwa orang yang percaya kepada Tuhan Yesus akan beroleh hidup kekal (Yoh. 3:16). Dengan "percaya" kita bisa menghayati anugerah Allah, yaitu hidup kekal yang diberikan kepada umat Allah melalui kematian Anak Allah. Sehingga dapat disimpulkan bahwa iman adalah jalan untuk masuk ke dalam hidup kekal.

Dalam teks ini juga dinyatakan bahwa orang-orang bisa percaya kepada Yesus adalah melalui "pemberitaan" para murid. Kata "pemberitaan" dalam teks

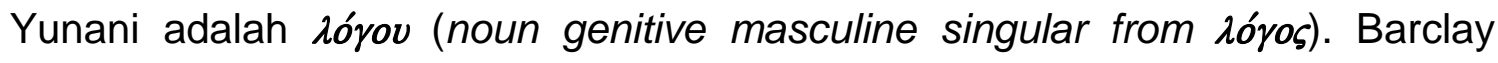
menerjemahkan kata ini sebagai "sesuatu yang dikatakan (misalnya; perkataan, firman, ajaran); firman (dalam Kristologi Yohanes); pertanggung jawaban (Ibr. 4:13); nilai (Kis. 20:24); sebab, alasan (Kis. 18:14); dakwaan (Kis. 19:38); perkara (Kis. 8:21); buku (Kis. 1:1)". ${ }^{49}$ Dalam NKJV kata ini diterjemahkan

\footnotetext{
${ }^{48}$ Leon Morris, Teologi Perjanjian Baru, H. Pidyarto O Carm., terj., (Malang: Gandum Mas, 2001), 381

${ }^{49}$ Barclay M. Newman Jr., Kamus Yunani - Indonesia..., 100
} 
"word" sementara dalam NIV diterjemahkan "message" dan dalam NLT diterjemahkan "testimony".

Frasa dia. tou/ lo,gou auvtw/n mengindikasikan bahwa kesaksian para rasul tersebut adalah tentang Kristus, dan kesaksian tersebut menjadi sebuah pendahuluan yang penting bagi iman. Berkaitan dengan hal ini Ryle menyatakan bahwa:

Let us mark how the "Word" preached is mentioned as the means of making man believe, "Faith cometh by hearing"... Hengstenberg thinks that the "word" here must include the writings of the Apostle as well as their sermons. ${ }^{50}$

Hal senada juga diungkapkan oleh Hendriksen yang menyatakan bahwa:

The means that is used in order to bring about faith is, as always, the word (their word, not as if they had invented it, but because they heard it, accepted it, preach it), the message of salvation (wether oral or written; cf. Ef. 2:20). ${ }^{51}$

\section{Ayat 21}

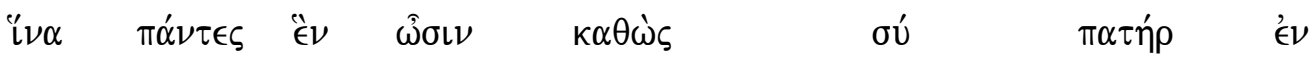

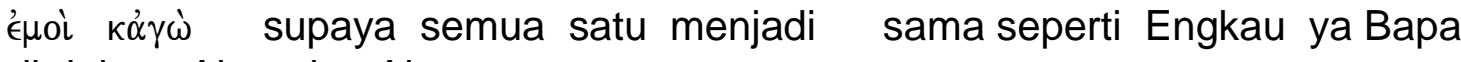
di dalam Aku dan Aku

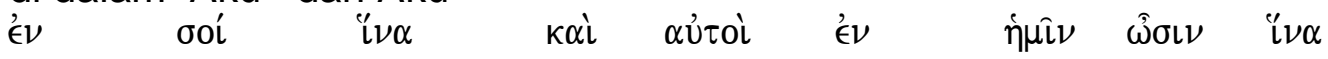
di dalam Engkau supaya juga mereka di dalam Kita berada supaya

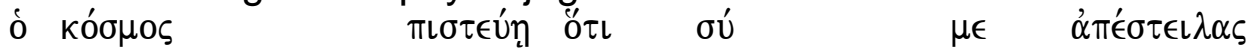
$\sim$ (manusia di) dunia percaya bahwa Engkau Aku telah mengutus ${ }^{52}$

supaya semua menjadi satu

sama seperti Engkau ya Bapa di dalam Aku dan

Aku di dalam Engkau

supaya mereka juga berada di dalam Kita

50 J.C. Ryle, Expository Thoughts on the Gospels: John..., 226-227

${ }^{51}$ William Hendriksen, New Testament Commentary..., 364

52 Hasan Sutanto (ed), Perjanjian Baru Interlinear Yunani-Indonesia..., 593 
supaya (manusia di) dunia percaya

bahwa Engkau telah mengutus Aku

ITB: supaya mereka semua menjadi satu, sama seperti Engkau, ya Bapa, di dalam Aku dan Aku di dalam Engkau, agar mereka juga di dalam Kita, supaya dunia percaya, bahwa Engkaulah yang telah mengutus Aku.

NIV: that all of them may be one, Father, just as you are in me and I am in you. May they also be in us so that the world may believe that you have sent me.

NKJV: that they all may be one, as You, Father, are in Me, and I in You; that they also may be one in Us, that the world may believe that You sent Me.

NLT: My prayer for all of them is that they will be one, just as you and I are one, Father -- that just as you are in me and I am in you, so they will be in us, and the world will believe you sent me.

Dalam ayat ini dipakai kata ¿ $\nu \alpha$ sebanyak tiga kali. ¿ $\nu \alpha$ merupakan kata penghubung agar, supaya; sehingga. ${ }^{53}$ Purpose is the usual meaning of the $\mathrm{i \nu \alpha}$ clause in koine. The mode of the verb is virtually always subjunctive. ${ }^{54}$ Dalam hal ini, Rienecker menjelaskan bahwa, "The first two clauses express the contend of prayer and the third expresses purpose". ${ }^{55}$ Kata "menjadi" dalam teks Yunani memakai kata $\hat{\sigma} \sigma \nu$ (verb subjunctive present active 3rd person plural from $\epsilon^{i} \mu i^{56}$ ). Barclay menerjemahkan kata ini sebagai adalah (menghubungkan pokok kalimat dengan sifatnya/pelengkapnya); berada, hidup; tinggal; terjadi; timbul; datang. ${ }^{57}$ Present dalam klausa ini menandakan timeless and linear. ${ }^{58}$

${ }^{53}$ Barclay M. Newman Jr., Kamus Yunani - Indonesia..., 80

54 William Douglas Chamberlain, An Exegetical Grammar Of The Greek New Testament, (Grand Rapids, Michigan: Baker Book House, 1988), 182

${ }^{55}$ Fritz Rienecker (ed), A Linguistic Key To The Greek New Testament, (Grand Rapids, Michigan: Zondervan Publishing House, 1980), 256

${ }^{56}$ Samuel Bangster (ed), The Analytical Greek Lexicon..., 444

${ }^{57}$ Barclay M. Newman Jr., Kamus Yunani - Indonesia..., 48 183

${ }^{58}$ William Douglas Chamberlain, An Exegetical Grammar Of The Greek New Testament..., 
Dengan demikian, pemakaian tense present menunjukkan bahwa hal itu sedang atau berkali-kali dilakukan

Dari hal-hal di atas dapatlah disimpulkan bahwa Yesus mendoakan kesatuan pengikut-Nya, bentuk yang dipakai dalam bahasa Yunani menunjuk pada suatu tindakan yang berkesinambungan: "terus-menerus bersatu", kesatuan yang berlandaskan kesamaan hubungan kepada Bapa dan Anak: "sama seperti Engkau, ya Bapa, di dalam Aku dan Aku di dalam Engkau, agar mereka juga di dalam Kita". Barrett menjelaskan bahwa:

Kesatuan gereja dengan tegas dapat disamakan dengan kesatuan Bapa dan Anak; Bapa aktif di dalam Anak -- Dialah (Bapa) yang melakukan pekerjaan-Nya.(Yoh. 14:10) -- dan terlepas dari Bapa pekerjaan Anak tidak berarti, dan sungguh mustahil; Anak juga di dalam Bapa, selamanya bersama-Nya dalam kesatuan Ke-Allahan, sama-sama aktif dalam penciptaan dan penebusan. Bapa dan Anak adalah satu dan sekalipun begitu tetap berbeda. Orang-orang percaya adalah berbeda dari Tuhan namun berdiam di dalam Tuhan, dan mereka sendiri ruang lingkup aktivitas Allah (Yoh. 14:12). ${ }^{59}$

Banyak penafsir Alkitab yang menyatakan bahwa kesatuan ini adalah kesatuan rohani dan bukannya kesatuan organisasi. Barrett berpendapat bahwa the existence of such a community is a supranatural fact which can be explained only as a result of a supernatural cause. ${ }^{60}$ Searah dengan hal itu, Bernard menyatakan bahwa kesatuan tersebut bukanlah kesatuan organisasi. Yesus sudah berkata sebelumnya bahwa domba-domba-Nya pada akhirnya akan menjadi satu kawanan, ketika mereka memiliki Seorang Gembala (10:18). Tetapi ungkapan-ungkapan mistis yang digunakan dalam bagian ini melebihi

\footnotetext{
${ }^{59}$ C.K. Barrett, The Gospel According To St. John..., 512

60 lbid.
} 
pemikiran tersebut. Karena la mendoakan kesatuan para murid-Nya yang mungkin dicapi dalam hidup rohani, di mana Bapa "di dalam" Anak dan Anak "di dalam" Bapa ${ }^{61}$ Lebih lanjut ia menyatakan:

The ideal is that all Christians may be evn $\mathrm{h}$ 'mi/h. "Abide in me" was the counsel of $15^{4}$ (cf. I Jn. $3^{24} 5^{20}$ ), but rightly obeyed this implies abiding in God; the use of the plural $\mathrm{h}$ 'mi/n here, recalling the plural

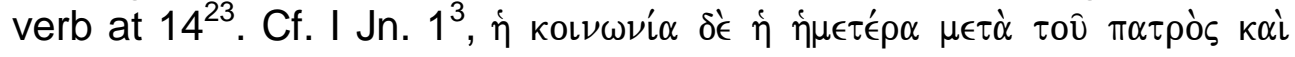

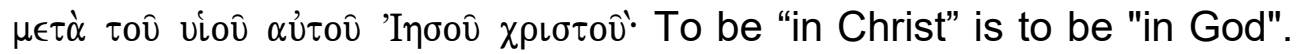
Those who are thus "in God" share the Divine life in common, and

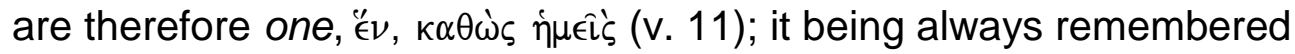
that $\kappa \alpha \theta \dot{\omega} \varsigma$ in such passage is only suggestive of a partial, not a complete, analogy (see on v. 18 above, and cf. $6^{57}$ ). ${ }^{62}$

Dengan demikian dapatlah ditarik kesimpulan bahwa kesatuan dengan Allah melalui Kristus tersebut yang memungkinkan kesatuan diantara orang percaya. Hal itu dikarenakan hanya orang-orang yang sudah mengalami kelahiran baru, dan berada di dalam Bapa dan di dalam Anak, yang satu secara rohani.

Frasa "di dalam" dalam teks Yunani adalah $€ \mathcal{~} \nu$. Wenham menjelaskan bahwa $€ \nu+$ datif berarti "di" atau "di dalam", karena datif juga dipakai untuk menyatakan tempat (lokatif). ${ }^{63} \in \mathcal{\epsilon}-$ preposisi dengan dativ dapat diartikan di dalam, di atas, pada, dengan tempat atau hal apapun, dengan gagasan utama bersandar/meletakkan. Bila dibandingkan dengan eis, into or unto, dan ek, out of or from, maka en berada diantara keduanya; eis menyiratkan gerakan ke dalam, dan ek gerakan ke luar dari, sementara en, di (dalam), yang berarti

\footnotetext{
61 John Bernard, A Critical And Exegetical Commentary..., 576

62 Ibid., 577

63 J.W. Wenham, Bahasa Yunani Koine..., 25
} 


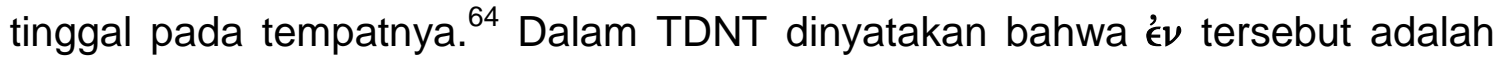
"the en of fellowship":

In John and 1 John we have the en of religious fellowship, often with eínai (Jn. 10:38; $1 \mathrm{Jn} .2: 5 \mathrm{~b}$, etc.) or ménein (Jn. 6:56; 1Jn. 2:6, etc.). Reciprocity is frequently stressed (Jn. 6:56; $1 \mathrm{Jn}$. 3:24, etc.). The Father is brought into the relationship, either with Jesus (Jn. 10:38) or with us (1Jn. 4:12-13, etc.). We thus have a triangle (Jn. 14:20; $17: 21 ; 1 \mathrm{Jn}$. 2:24). The formulas are neither ecstatic nor eschatological but mystical in a very broad sense with a strong personal and ethical reference (1Jn. 1:3); cf. construction with agápē and lógos (Jn. 15:10; 1Jn. 2:14). There is no hint of the sacred marriage, nor are there any Hellenistic or Gnostic parallels. ${ }^{65}$

Mereka yang "di dalam Kristus" maksudnya adalah orang Kristen. Secara khusus mereka yang dalam hubungan dengan Kristus, dalam iman Kristen. Kristus di dalam orang percaya dan sebaliknya, sebagai akibat dari iman dalam Dia. Berkenaan dengan bagaimana kesatuan itu bisa terjadi Bruce berpendapat bahwa:

That this vital unity through Christ with God is maintained and attested by indwelling Spirit is clear, even if this aspect of the Spirit's ministry is not spelled out expressly in these chapters as it is elsewhere in the NT (cf. I John 4:13, 'By this we know that we abide in him and he in us, because he has given us of his own Spirit'). ${ }^{66}$

Selanjutnya dinyatakan juga bahwa tujuan dari kesatuan tersebut adalah "supaya dunia percaya, bahwa Engkaulah yang telah mengutus Aku". Kata percaya tersebut dalam teks Yunani adalah $\pi \iota \sigma \tau \epsilon u ́ \sigma \eta$ (verb subjunctive aorist active 3rd person singular from $\pi \iota \sigma \tau \epsilon u ́ \omega)$. Modus subjunktif dipakai untuk

64 Spiros Zodhiates (ed), The Complete Word Study Dictionary: New Testament, (Chattanooga: AMG Publisher, 1993), 579

${ }^{65}$ Gerhard Kittel, Theological Dictionary Of The New Testament: Abridged In One Volume, (Grand Rapids, Michigan: Wm.B. Eerdmans Publishing Company, 1986), 234

${ }^{66}$ F.F. Bruce, The Gospel of John..., 336 
menyatakan sesuatu yang tak tentu. ${ }^{67}$ Lebih lanjut modus ini adalah modus yang menegaskan kemungkinan objektif. Modus ini menganggap bahwa tindakan bukanlah suatu fakta yang terjadi sekarang, tetapi kemungkinan atau berpotensi menjadi fakta, tergantung kepada situasi. Ini adalah modus probabilitas, yang dipergunakan dalam nasihat, peringatan, pertanyaan deliberatif (menimbang), larangan, dan kalimat kondisi. ${ }^{68}$ Mengenai kata "percaya" tersebut Thayer menyatakan " $\iota \iota \sigma \tau \epsilon u ́ \omega$ followed by ö $\iota$ with a sentence in which either the nature and dignity of Christ or his blessings are set forth" ${ }^{69}$ Bila kita kaitkan dengan teks di bagian lain maka jelaslah bahwa tujuan atau konsekuensi dari kesatuan itu adalah bahwa dunia paling sedikit akan diyakinkan (bdk. 16:8) mengenai misi Yesus dan bahwa la adalah "Juruselamat dunia" (4:42).

\section{Kesatuan adalah Akibat Kemuliaan yang Diberikan (Ayat 22-23)}

\section{Ayat 22}

$\kappa \dot{\alpha} \gamma \hat{\prime}$ dan Aku $\delta \epsilon^{\prime} \delta \omega \kappa \alpha$

$$
\tau \grave{\nu} \nu \quad \delta o ́ \xi \alpha \nu
$$

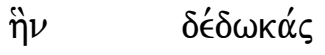

$\kappa \alpha \theta \dot{\omega} \varsigma$

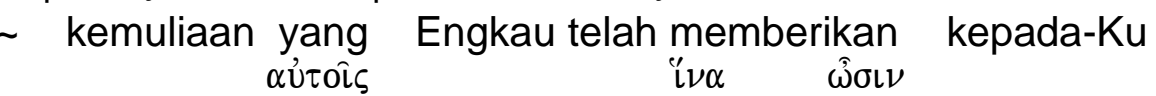

Hol

$\dddot{\epsilon} \nu$ telah memberikan kepada mereka supaya mereka menjadi satu sama seperti $\dot{\eta} \mu \in \hat{\imath} \varsigma$ $\dddot{\epsilon} v$.

\footnotetext{
${ }^{67}$ Ola Tulluan, Bahasa Yunani, (Batu: Literatur YPPII, 2007), 160

${ }^{68}$ William Douglas Chamberlain, An Exegetical Grammar Of The Greek New Testament..., 82

69 Joseph Henry Thayer, A Greek-English Lexicon Of The New Testament, (Cambridge, Massachusetts: International Bible Translator Inc, 1889), 212
} 
Kita (adalah) satu $^{70}$

dan Aku

telah memberikan kepada mereka

kemuliaan yang Engkau telah memberikan kepada-Ku

supaya mereka menjadi satu

sama seperti Kita (adalah) satu

ITB: Dan Aku telah memberikan kepada mereka kemuliaan, yang Engkau berikan kepada-Ku, supaya mereka menjadi satu, sama seperti Kita adalah satu:

NKJV: And the glory which You gave Me I have given them, that they may be one just as We are one:

NIV: I have given them the glory that you gave me, that they may be one as we are one:

NLT: I have given them the glory you gave me, so they may be one as we are one.

Ayat ini dimulai dengan kata $\kappa \dot{\gamma} \gamma \grave{\omega}$ (conjunction coordinating AND pronoun personal nominative singular). Kata ini adalah kependekan dari кai $\dot{\epsilon} \gamma \dot{\omega} .{ }^{71}$ Barclay menerjemahkannya dan aku; tetapi aku; aku juga; akupun. ${ }^{72}$ Kata kai. merupakan kata penghubung, dengan demikian penggunaan kai tersebut menunjukkan bahwa ayat 22 ini berhubungan dengan bagian selanjutnya, yaitu ayat 23. Menurut Pink pemakaian kata "dan" di awal ayat ini sebenarnya menunjukkan bahwa apa yang dikatakan selanjutnya menjelaskan apa yang telah diucapkan Tuhan pada ayat sebelumnya. Persatuan itu merupakan "akibat" dari "kemuliaan yang diberikan" kepada kita. ${ }^{73}$ Kata "telah memberikan"

\footnotetext{
${ }^{70}$ Hasan Sutanto (ed), Perjanjian Baru Interlinear Yunani-Indonesia..., 593-594

${ }^{71}$ Samuel Bangster (ed), The Analytical Greek Lexicon..., 205

${ }^{72}$ Barclay M. Newman Jr., Kamus Yunani - Indonesia..., 83

${ }^{73}$ A.W. Pink, Tafsiran Injil Yohanes..., 355
} 
dalam teks Yunani adalah $\delta \dot{\delta} \delta \omega \kappa \boldsymbol{\alpha}$ (verb indicative perfect active 1st person singular from $\delta(\delta \omega \mu \iota)$. Tense perfek menyatakan suatu keadaan yang sekarang ada sebagai akibat dari suatu yang telah dilakukan (a present state resulting from a past action); suatu tindakan yang telah rampung di masa lampau tanpa memerlukan tindakan ulang, dengan hasil yang positif dan pasti di masa kini. ${ }^{74}$ Sedangkan voice active bermakna subjek sendiri yang melakukan tindakan. Dalam hal ini, subjek menyebabkan, menghasilkan dan mengadakan tindakan itu. $^{75}$

Dari susunan kalimatnya terlihat jelas bahwa subjeknya adalah Yesus. Dari hal ini dapat disimpulkan bahwa untuk terjadinya kesatuan, Tuhan Yesus sendirilah yang memiliki inisiatif dan melakukan tindakan memberi "kemuliaan" tersebut. la dapat melakukan hal itu karena Bapa telah memberikan "kemuliaan" itu kepada-Nya. Berkenaan dengan hal itu, Hendriksen menjelaskan bahwa: "By 'I given them' he means that he (i.e., Jesus) manifested himself in the lives of believers. To able to say, 'Christ only, always, living in us,' is their glory". ${ }^{76}$

Kata "kemuliaan" dalam teks aslinya adalah $\delta o ́ \xi \alpha \nu$ (noun accusative feminine singular from $\delta \delta_{\xi} \alpha^{77}$ ), dapat diartikan kemuliaan; kemegahan; cahaya;

\footnotetext{
${ }^{74}$ J.W. Wenham, Bahasa Yunani Koine..., 121

${ }^{75}$ William Douglas Chamberlain, An Exegetical Grammar Of The Greek New Testament...,

${ }^{76}$ William Hendriksen, New Testament Commentary..., 365

${ }^{77}$ Samuel Bangster (ed), The Analytical Greek Lexicon..., 106
} 80 
hadirat Allah; surga; makhluk surgawi yang mulia. $^{78}$ Zodhiates mencatatkan bahwa:

Kemuliaan dan memuliakan Yesus Kristus artinya adalah penyataan sifat-sifat dasar keilahian-Nya, yaitu bahwa la ada dalam kepatuhan akan Bapa, meskipun terselebung dari manusia oleh pembatasan akan inkarnasi (Yoh. 17:5; 1Kor. 2:8; Ibr. 1:3; Yak. 2:1). Ketika dalam Yohanes 17:1, 5, 24 Tuhan Yesus berdoa untuk Pemuliaan-Nya oleh Bapa, la sedang menantikan kemegahan yang dirindukan-Nya ketika keluar dalam kebangkitan, dimana natur asli dan karya penebusanNya dihargai dan dirayakan oleh orang beriman. Itu hanyalah sebagian maksud yang dianggap berasal dari kata "permuliakan", karena ada suatu kemuliaan yang akan datang. Ini akan melengkapi kemuliaan sekarang ini dari kebangkitan rohani orang percaya yang dengannya semua diikutkan dalam kebangkitan dan pemuliaan di masa yang akan datang ( Yohanes 17:24). ${ }^{79}$

Bernard menjelaskan tentang "kemuliaan" yang secara khusus terdapat dalam ayat 22 ini dengan menyatakan bahwa:

It is not the glory of the Eternal Word, spoken in v. 24. That a faithful diciple may hope to see, but not to share (although I Pet. $5^{1}$ seems to claim more than is suggested in $\mathrm{Jn}$.). It is rather the glory of the Incarnate Word (see on $\mathrm{I}^{14}$ ), which Jesus exhibited in His earthly ministry $\left(2^{11}\right)$, the manifestation of the Divine Nature in man. His diciples were the branches of which He was the Vine $\left(15^{5}\right)$, or, as it is expressed in 2 Pet. 14, they had become "partakers of the Divine Nature". 80

Sementara itu, Barclay menerangkan bahwa Yesus membicarakan hal kemuliaan itu dalam tiga cara, yaitu: (a) Salib adalah kemuliaan-Nya. Yesus tidak bicara bahwa la disalibkan; Dia bicara bahwa la dimuliakan. (b) Kepatuhan Kristus yang sempurna kepada kehendak Allah adalah kemuliaan-Nya. (c) Kemuliaan Yesus terletak pada kenyataan bahwa, dari hidup-Nya manusia

\footnotetext{
${ }^{78}$ Barclay M. Newman Jr., Kamus Yunani - Indonesia..., 43

${ }^{79}$ Spiros Zodhiates (ed), The Complete Word Study Dictionary..., 480

80 John Bernard, A Critical And Exegetical Commentary..., 578
} 
melihat hubungan-Nya yang khusus dengan Allah. ${ }^{81}$ Menurut Morris, Yohanes menggunakan gagasan tentang "kemuliaan" secara sangat tidak biasa - apa yang oleh Origenes disebut "kemuliaan dalam kerendahan (humble glory). ${ }^{82}$ Lebih lanjut ia menyatakan bahwa:

Bagi Yohanes, kemuliaan, yaitu kemuliaan yang sejati, tampak kalau orang yang sebenarnya bisa mendapat kedudukan mulia dan tinggi, malah memilih kedudukan pengabdian yang sederhana. Kemuliaan sangat terlihat dalam Salib, sebab disitulah Dia yang tidak perlu mati, telah menderita demi kepentingan orang lain. Jadi, ketika Yohanes mengatakan bahwa Yesus "dimuliakan", seringkali yang dia maksudkan adalah Yesus disalibkan (7:39; 12:16, 23; 13:31; bdk. 21:19). Memahami kemuliaan sebagaimana Yohanes memahaminya berarti melihat bayang-bayang Salib dalam seluruh kehidupan Yesus. ${ }^{83}$

Jadi yang dimaksudkan dengan kemuliaan dalam ayat ini ialah kemuliaan yang diperoleh-Nya sebagai Pribadi yang menjelma, sebagai ganjaran bagi pekerjaan-Nya di bumi.

Dalam Yohanes, iman juga melihat kemuliaan dari Kristus yang berinkarnasi $(1: 14 ; 2: 11 ; 11: 40)$. Dóxa Kristus ini tidaklah kelihatan dengan sendirinya. Ia harus dimuliakan (Yoh. 7:39; bdk. 12:23; 13:31; 16:14; doa di 17:5). Jalan masuk ke dalam kemuliaan adalah melalui salib (13:31), di mana dóxa Tuhan dinyatakan, meskipun begitu terdapat keterlibatan di dalamnya. Hal

${ }^{81}$ William Barclay, Pemahaman Alkitab Setiap Hari: Injil Yohanes, Fs. 8-21, S. Wismoady Wahono, terj., (Jakarta: BPK Gunung Mulia, 1985), 343-344

${ }^{82}$ Leon Morris, Teologi Perjanjian Baru..., 341

${ }^{83}$ Ibid., 376 
itu dipandang dari sudut kerinduan orang percaya, oleh Roh, melihat kemuliaan Kristus. $^{84}$

Demikian juga Barrett menegaskan bahwa kemuliaan yang diterima oleh mereka harus diterima melalui iman dalam kematian dan kebangkitan Tuhan Yesus, dan mereka menyatakan kemuliaan itu melalui kerendahatian dan penderitaan. ${ }^{85}$ Jadi kematian-Nya di kayu salib adalah tindakan paling menonjol dalam pemuliaan Allah. Kemuliaan yang dinyatakan Yesus ini, jelas merupakan satu kemuliaan yang terselubung. Itu hanya dapat dilihat dengan mata iman.

\section{Ayat 23}

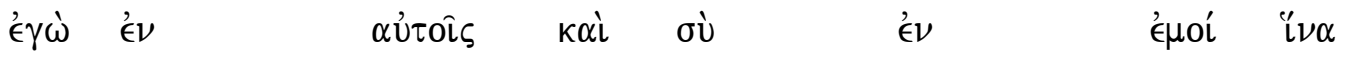
Aku di dalam mereka dan Engkau di dalam Aku supaya

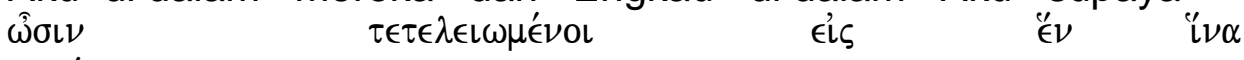
$\gamma \iota \nu \omega ́ \sigma \kappa \eta ̣$ \{mereka boleh (dengan) sempurna\} menjadi satu supaya tahu

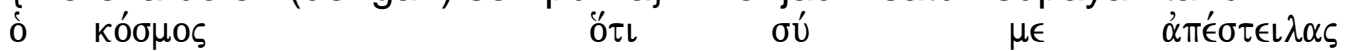

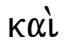

(manusia di) dunia bahwa Engkau Aku telah mengutus dan $\eta \dot{\eta} \gamma \alpha \dot{\pi} \pi \eta \alpha \alpha$

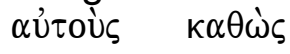

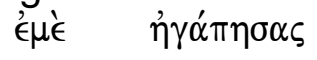
Engkau telah mengasihi mereka sama seperti Aku Engkau telah mengasihi ${ }^{86}$

Aku di dalam mereka dan Engkau di dalam Aku

supaya \{mereka boleh (dengan) sempurna\} menjadi satu supaya (manusia di) dunia tahu bahwa Engkau telah mengutus Aku dan Engkau telah mengasihi mereka seperti Engkau telah mengasihi Aku

\footnotetext{
${ }^{84}$ Gerhard Kittel, Theological Dictionary Of The New Testament..., 180

${ }^{85}$ C.K. Barrett, The Gospel According To St. John..., 513

${ }^{86}$ Hasan Sutanto (ed), Perjanjian Baru Interlinear Yunani-Indonesia..., 594
} 
ITB: Aku di dalam mereka dan Engkau di dalam Aku supaya mereka sempurna menjadi satu, agar dunia tahu, bahwa Engkau yang telah mengutus Aku dan bahwa Engkau mengasihi mereka, sama seperti Engkau mengasihi Aku.

NIV: I in them and you in me. May they be brought to complete unity to let the world know that you sent me and have loved them even as you have loved me.

NKJV: I in them, and You in Me; that they may be made perfect in one, and that the world may know that You have sent Me, and have loved them as You have loved Me.

NLT: I in them and you in me, all being perfected into one. Then the world will know that you sent me and will understand that you love them as much as you love me.

Menurut Barrett sangatlah sulit untuk menarik suatu pembedaan yang jelas antara "Aku di dalam mereka" dan "mereka di dalam Kita" (ay. 21). Mungkin saja dikatakan dengan kebenaran yang sama bahwa Kristus adalah di dalam Bapa dan Bapa di dalam Kristus, dan hubungan antara para murid dan keallahan merupakan suatu timbal balik yang serupa. ${ }^{87}$ Berkenaan dengan itu Rainsford menyatakan bahwa:

"I in them" - not only with them forever, not only for them, and againts all those that are opposed to them, not only near them, but "in them", as their very life and glory. In them as the head doth live in the members of the body, in them as the glory fills the temple of the Lord, in them evermore, the incarnate fullness of God in their souls. ${ }^{88}$

Sementara itu, pendapat Hendriksen berkaitan dengan ayat 23 ini adalah bahwa:

When God dwells in the Son, and he (through the Spirit) dwells in those who have placed their trust in him, then, naturally, these believers become partakers of all the riches that are in Christ:

${ }^{87}$ C.K. Barrett, The Gospel According To St. John..., 513

${ }^{88}$ Marcus Rainsford, Our Lord Prays For His Own: Thoughts on John 17, (Chicago: Moody Press, 1958), 417 
pardon, righteousness, love, joy, knowledge, wisdom, etc. And when all the members of the Church Universal have become partakers of these blessings, the Church, of course, will be one, just as Father and Son are one. And this is the very reason why Christ gave all this glory to believers, namely, "in order that they may become perfectly one" (literally, "in order that they may have been brought completely to oneness"). ${ }^{89}$

Selanjutnya dalam ayat ini juga menyatakan bahwa kesatuan itu mempunyai tujuan, yaitu "agar dunia tahu, bahwa Engkau yang telah mengutus Aku dan bahwa Engkau mengasihi mereka, sama seperti Engkau mengasihi Aku". Kata "tahu" dalam teks Yunani adalah $\gamma \iota \nu \omega \sigma \kappa \eta$ (verb subjunctive present active 3rd person singular from $\iota \nu \omega \sigma \sigma \kappa \omega)$. Barclay menerjemahkan kata ini dengan "mengetahui; mengerti; merasa; mengenal dalam arti bersetubuh dengan (Mat 1.25; Luk 1.34)". ${ }^{90}$ Jadi tujuan dalam ayat 23 ini memperluas tujuan dalam ayat 21, yaitu bukan hanya mengenal Yesus tetapi juga kasih Bapa.

Berdasarkan analisis eksegetis di atas jelaslah terdapat suatu hubungan mistis antara orang-orang percaya dan Kristus, atau orang-orang percaya dan Allah. Gagasan ini diungkapkan dengan frasa yang khas, yaitu "ada di dalam" Yesus. Hal ini seringkali disebut sebagai "mistisisme Yohanes" dan tidak ada definisi yang jelas. Ada saling tinggal dari orang-orang percaya di dalam Kristus dan Kristus di dalam orang-orang percaya. Ini sejalan dengan Anak tinggal di dalam Bapa dan Bapa tinggal di dalam Anak (Yoh. 17:21, 23). Namun dalam kesatuan tersebut tidak ada penggabungan pribadi atau penghilangan identitas

\footnotetext{
${ }^{89}$ William Hendriksen, New Testament Commentary..., 365

${ }^{90}$ Barclay M. Newman Jr., Kamus Yunani - Indonesia..., 33
} 
manusia. Tidak ada bukti bahwa mistisisme Yohanes menimbulkan kondisi ekstase atau trance. Sebaliknya, hal itu adalah mistisisme pribadi dan persekutuan etika yang meliputi kehendak ketimbang emosi. Jadi mistisisme ini dibarengi dengan tuntutan etis. Selain itu, kesatuan orang percaya dengan Kristus mencakup juga kesatuannya dengan orang lain, dan kesatuan tersebut mempunyai kepentingan dan tujuan bersama.

William Inge menyatakan bahwa Injil Yohanes adalah Injil Spiritual, bahkan ada yang menamakannya piagam persatuan Kristen sehingga kekristenan yang diajarkan oleh rasul Yohanes tidak lain adalah semacam ajaran kekristenan mistik. Persatuan mistik juga merupakan salah satu diantara teologi Paulus dan bahkan inti dari agama yang diajarkan oleh sang rasul karena elemen-elemen esensial tentang persatuan mistik ditemukan dalam surat-surat kiriman rasul Paulus. Oleh sebab itu, kedua rasul tersebut disinyalir oleh teolog-teolog tertentu telah mengajarkan doktrin persatuan mistik. ${ }^{91}$

Istilah mistik dibentuk dari istilah Yunani 'muein' yang berarti 'menutup'. Maksudnya ialah menutupi mata dan mulut demi untuk mengarahkan konsentrasi dan keterbukaannya ke dalam diri, kepada jiwa dan hubungannya dengan Allah. Hakikat mistik ialah kerinduan manusia untuk mempunyai hubungan dan bahkan persatuan langsung dengan Allah. Keyakinan mistik ialah bahwa manusia diciptakan dan disanggupkan melalui 'askese' dan 'meditasi' untuk bersatu dengan yang Maha Tinggi. Dalam sejarah gereja Mistik Kristen

${ }^{91}$ Hali Daniel Lie, Jurnal Teologi dan Pelayanan “Veritas”, (Malang: SAAT, 2001), 288 
muncul dan berkembang sebagai reaksi terhadap keadaan gereja yang terlalu menekankan segi-segi objektif dan lahiriah dan tenggelam dalam formalisme dan tradisionalisme..$^{92}$

Lain dengan mistik agama-agama lain, tokoh Mistik Kristen pada umumnya dapat mempertahankan perbedaan hakiki antara Allah dan jiwa manusia ('duality'). Roh manusia yang bersatu dengan Roh Allah tidak menghapus status 'ciptaan' buat manusia. Roh manusia tidak seolah-olah 'terlarut' dalam Roh Allah dan kehilangan identitasnya. Roh manusia bukan juga unsur ilahi yang terkurung dalam tubuh manusia. Memang dalam Mistik Kristen terdapat juga segi-segi yang berbahaya dan ada kelemahan-kelemahan teologis. Namun demikian adalah segi 'mistik' dalam iman Kristen dan dalam Alkitab, dalam arti bahwa Alkitab menekankan hubungan pribadi antara manusia yang diselamatkan dan Kristus. Bahkan Alkitab mengajarkan tentang kesatuan antara Allah dan manusia (union with Christ), suatu kesatuan yang penuh rahasia (musterion) ${ }^{93}$

92 Dietrich Kuhl, Sejarah Gereja II: Gereja Katolik Roma Di Dalam Lingkungan dan Kebudayaan Eropa Barat Pada Abad-abad Pertengahan (500-1500), (Batu: YPPII, 1997), 145146

${ }^{93}$ Ibid., 147-152 